Studia nad Autorytaryzmem i Totalitaryzmem 43, nr 3

Wrocław 2021

https://doi.org/10.19195/2300-7249.43.3.7

\author{
ARTUR ŁAWNICZAK \\ ORCID: 0000-0002-0611-7176 \\ Uniwersytet Wrocławski \\ artur.lawniczak@uwr.edu.pl
}

\title{
Widziana z III RP prawnopolityczna tożsamość Polski Ludowej
}

Slowa kluczowe: Polska, socjalizm, demokracja, lud, konstytucja, totalitaryzm, autorytaryzm.

\section{VIEW FROM THE THIRD POLISH REPUBLIC ON JURIDICAL-POLITICAL IDENTITY OF POLISH PEOPLE'S REPUBLIC}

\begin{abstract}
The Polish People's Republic is a matter of the past, but not entirely. Finally, nolens volens, the current version of our old statehood is its continuation, manifested in numerous formal solutions. This is in an evident manner a republican form of statehood and a democratic system. Similar to the Stalinist Constitution of 1952, it was called a people's democracy, but from 1976 a socialist democracy as the effect of changes in the written Ius Supremum. In the political practice, after partial totalitarianism came authoritarianism. Before 1980, there were no changes in the institutional state power system. Theoretically, the first in this structure was the Sejm — the official emanation of the Volonté Générale. The collective head of the state was the State Council with a more republican identity than the contemporary president. The Council of Ministers actually has the same shape as before 1989, as well as the parliamentary cabinet system of government. In similar situation are: the Supreme Court, the Administrative Court, the Constitutional Court, the State Tribunal, the Ombudsman, and the Supreme Chamber of Control. Their identity and philosophy of action are similar to the socio-political reality from before the system transformation, mythologized in many aspects.

This does not mean that it is fiction. Its result, according to the ancient nomenclature, was the transformation of socialist democracy into bourgeois people's rule. Actually, we rather talk about the transition from "communism" or totalitarianism to liberal democracy. But Marxist-Leninist classics claimed that communism will be a post-state society without class opposites. Finally, in the Polish People's Republic real socialism existed, with partial totalitarian character, replaced shortly after Stalin's death by authoritarianism, which in the socio-economic and cultural spheres tolerates spontaneous manifestations of activity, without inspirations of the authorities, its culmination being in the time of the several-month-long "Carnival of Solidarity". The Gdańsk Agreement we can
\end{abstract}


understand as a social agreement, later transformed into the Round Table Agreements. After the continuation of these events it is possible to find on the constitutional ground in 1989, and then in 1997, when the new, formalized and complete Highest Law was created, as a formal recapitulation of political transformation.

So we observe the mild transition of the Polish People's Republic into the Third Polish Republic. The first one does not exist in the text of the actual Constitution, but it is impossible to not see a certain continuity.In the situation of the important difference between the two forms of our statehood - old and new - probably in the case of a system transformation there significant revolutionary accidents would have been unavoidable, but they have not happened.. Parliamentary democracy was liberalized, which manifested in in the replacement of Gierek's famous slogan of moral and political unity with the conviction that an official electoral struggle for power between parties is necessary. The second important change in the political sphere is the greater consideration of Montesquieu's dogma concerning the division of state power. Other changes are less significant. Also, the republican democracy has maintained its fundamental identity, although the system of institutionalized rule had changed.

Keywords: Poland, socialism, democracy, people, constitution, totalitarianism, authoritarianism.

Powojenna postać, dzisiaj zazwyczaj traktowanej w Głównym Nurcie jako nieszczególnie ciekawe zjawisko, polskiej państwowości miała swoją, przejawiającą się w różnych wymiarach, specyfikę, która zasługuje na to, aby ją przypominać i analizować, tum ne oblivio nigrescere. W tym tekście pochylimy się nad jej ustrojowo-jurydycznym wymiarem, przede wszystkim po to, aby pokazać podobieństwa i różnice z dzisiejszą inkarnacją rodzimej państwowości ${ }^{1}$.

Ta ostatnia pojawiła się w 1989 roku, kiedy to wskutek porozumień Okrągłego Stołu doszło do „historycznego kompromisu” między dotychczasową władzą a „rozsądną częścią solidarnościowej opozycji”, skupioną wokół Lecha Wałęsy, co skutkowało kontraktowymi wyborami do Sejmu i nacechowaną konfrontacyjnością senacką elekcją, oznaczającymi demoliberalizację systemu władania. Znalazło to swoje odzwierciedlenie pod koniec „owego roku”, kiedy doszło do zmiany nazwy państwa z Polskiej Rzeczypospolitej Ludowej na Rzeczpospolitą Polską. Oznaczało to nomenklaturowy powrót do stanu sprzed 22 lipca 1952 roku, gdy to nowa ustawa zasadnicza zastąpiła RP PRL-em, co było zwieńczeniem powojennej transformacji ustrojowej. Wynika z tego, że Polska Ludowa występuje jako „przerwa w życiorysie RP”, ergo powinna reprezentować przynajmniej częściowo odmienny teoretyczno-historiozoficzny paradygmat.

${ }^{1} \mathrm{~W}$ historycznoprawnym ujęciu nad zagadnieniem tym, widzianym w szerszej perspektywie, obejmującej także międzywojenną RP, pochyliła się dwójka renomowanych autorów w poznawczo ciekawym i dość świeżym tekście. Zob. E. Kozerska, T. Scheffler, Retoryka ciagtości: o dziedzictwie prawnym II Rzeczypospolitej i rzadach komunistycznych, „Studia nad Autorytaryzmem i Totalitaryzmem" 39, 2017, $\mathrm{nr}$ 2, s. 53-79. W niniejszym opracowaniu ograniczymy się do zestawiania Polski Ludowej z III RP, choć nie da się ukryć, że w oficjalno-konstytucyjnym wymiarze współcześnie znacznie chętniej akcentuje się związki współczesnej postaci rodzimej państwowości z II Rzecząpospolitą, chętnie traktując PRL per non est jako swoistą „czarną dziurę” czy też „wstydliwy i godny zapomnienia epizod" w naszej historii. 
Nie jest to wszakże bynajmniej oczywiste mimo usilnego przekonywania głosicieli „kanonicznej”, lansowanej w szkołach i największych mediach, wersji najnowszych rodzimych dziejów. Jednak ,diabeł tkwi w szczegółach”, względnie konkretach, co sprawia, że nie zaszkodzi im się przyjrzeć.

Przypomnijmy więc, że w wypadku klasycznych wielkich rewolucji, a mianowicie niderlandzkiej, angielskiej, amerykańskiej, francuskiej i rosyjskiej, ustrojowy przełom wyrażał się przede wszystkim w zmianie formy państwa z monarchicznej na republikańską, tymczasem w naszym przypadku bynajmniej nie mamy do czynienia $\mathrm{z}$ takim zjawiskiem, bo przecież ustanowiona na początku II RP republikańskość polskiego państwa utrzymuje się niezmiennie do naszych czasów. Nie znaczy to jednak, że jej natężenie jest jednakowe. O tym, że było ono większe w poprzednim ustroju, świadczy to, iż w pierwszym zdaniu Aktu Konstytucyjnego z 1952 roku stwierdzono jednoznacznie, że „Polska Rzeczpospolita Ludowa $^{2}$ jest republiką ludu pracującego" 3 . Dla porównania w dzisiaj obowiązującym odpowiedniku „konstytucyjnego wzmożenia” z połowy ubiegłego wieku w ogóle nie odnajdziemy słowa republika, co wypada odczytać jako lekceważenie zagadnienia formy państwa ${ }^{4}$.

${ }^{2}$ Rozważana była inna wersja oficjalnej nazwy państwa, o czym dowiadujemy się z zapisków, jakie poczynił w 1950 r. ówczesny Przywódca Partii i Państwa podczas konsultowania ze Stalinem treści niektórych fragmentów nowego pozytywnoprawnego Ius Supremum. Otóż „w pierwszym punkcie sporządzonej po rosyjsku notatki dotyczącej zagadnień konstytucyjnych Bierut zapisał ,nazwa - PSR", co zapewne oznacza proponowaną nazwę państwa: Polska Republika Socjalistyczna”, jednakże ostatecznie ,nie wprowadzono [...] nazwy Polska Republika Socjalistyczna, pozostając przy wersji Polska Rzeczpospolita Ludowa, proponowanej w projekcie konstytucji z 8 września 1950 r.”, K. Persak, ,, Troskliwy opiekun i światty doradca Polski Ludowej - poprawki Józefa Stalina do Konstytucji PRL z 22 lipca 1952 r., [w:] PRL. Trwanie i zmiana, red. D. Stola, M. Zaremba, Warszawa 2003, s. 190, 191. Radziecki polityk zapewne uznał, że rekomendowana przez sekretarza generalnego PZPR nazwa grzeszy nadgorliwym zapatrzeniem w sowiecką nomenklaturę, w związku z czym zgodnie $\mathrm{z}$ hasłem „socjalistyczne w treści, narodowe w formie” wybrał rozwiązanie bardziej zgodne z polską tradycją. Doszło w ten sposób do powtórzenia sekwencji z 1918 r., kiedy to najpierw progresywny Tymczasowy Rząd Ludowy proklamował w Lublinie Republikę Polską, po czym uznano jednak, że Rzeczpospolita Polska jest lepszym, głębiej osadzonym w rodzimych dziejach określeniem.

3 Konstytucja Polskiej Rzeczypospolitej Ludowej uchwalona przez Sejm Ustawodawczy 22 lipca 1952 r., preambuła, http://isap.sejm.gov.pl/isap.nsf/download.xsp/WDU19520330232/O/ D19520232.pdf (dostęp: 13.03.2021).

${ }^{4}$ Co prawda dość często twierdzi się, że rzeczpospolita jest synonimem republiki, w związku z czym nie trzeba osobno deklarować republikańskości polskiej państwowości, ale pogląd ten podlega dużemu podważeniu, gdy wspomnimy Rzeczpospolitą Obojga Narodów, która przecież była monarchią, a „rzeczpospolitość” w tym wypadku kojarzy się z unią, suprapaństwowym związkiem królestwa i wielkiego księstwa, a zatem analizowany tu termin byłby odpowiednikiem angielskiego pojęcia wspólnota (commonwealth) lub niemieckiej Rzeszy (Reich). Po fiasku federacyjnych planów Piłsudskiego możemy co najwyżej uważać, że zachowanie przedrozbiorowej nazwy państwa zachęca do przyszłej fuzji, natomiast zasadniczo Rzeczpospolita oznacza mające dowolną formę ustrojową suwerenne państwo polskie. Więcej na ten temat w A. Ławniczak, M. Masternak-Kubiak, Republikańska forma państwa w ujęciu Konstytucji RP, „Państwo i Prawo” 1999, nr 8, s. 40-52. 
Jeśli chodzi o republikańską aksjologię, to raczej nie natrafimy na odniesienia do niej ani w fundamentalnym akcie jurydycznym z szóstej dekady poprzedniego stulecia, ani w kolejnym sformalizowanym zwieńczeniu rodzimego konstytucjonalizmu. Inaczej wygląda kwestia nacechowanych republikańskością instytucji, albowiem w obu przypadkach ustrojodawcy uznali za konieczne nie tylko podkreślenie znaczenia wybieralności ${ }^{5}$, ale także hołdowanie kadencyjnemu dogmatowi również w odniesieniu do głowy państwa. Najistotniejsze wszak jest to, że na aktualnym etapie rozwoju prawnopaństwowego ponownie mamy do czynienia z prezydenturą, natomiast podczas „,ciemnej nocy komunizmu” ${ }^{\prime}$ zniesiono ją na rzecz kolektywnej głowy państwa, którą to konstrukcję należy uznać za bardziej odpowiednią dla republikańskiego państwa niż taką, która mechanicznie naśladuje monarchiczny etalon. PRL-owska Rada Państwa była z pewnością mniej monarchoidalna niż wprowadzony na polski grunt ustrojowy w 1921 roku prezydencki paradygmat, wynoszący Pierwszego Obywatela ponad resztę politycznego Narodu, co jest na pewno niełatwe do pogodzenia z konsekwentnie rozumianym egalitaryzmem ${ }^{7}$. Ponosi on co prawda konstytucyjną odpowiedzialność, ale, podobnie jak inni piastuni prominentnych stanowisk lub funkcji w zinstytucjonalizowanym aparacie władania, przed mającym międzywojenny

${ }^{5}$ Nie jest ona absolutnie niekompatybilna z monarchicznością, o czym dobitnie świadczy przedrozbiorowa historia Polski, ale współcześnie w Europie i nie tylko w niej miejsce na tronie jest dziedziczone, natomiast prezydenci są w ten lub inny sposób obierani. Wprawdzie casus starszego i młodszego Busha pokazuje, że także w republice zdarza się dziedziczenie najwyższego stanowiska w państwie, ale nie ma ono obligatoryjnego charakteru i traktowane jest raczej jako „,wypadek w ustrojowej praktyce" niż godne pochwały zjawisko.

${ }^{6} \mathrm{Na}$ podstawie ustaleń marksizmu-leninizmu-stalinizmu trzeba orzec, że określenie to jest przesadne, względnie nieadekwatne, albowiem według klasyków komunizm nastanie dopiero wówczas, gdy w ogólnoglobalnej skali zostanie zniesiona własność prywatna. Wówczas zniknie konieczność istnienia państwa, będącego według marksistowskiej dogmatyki „organem panowania klasowego". Takie określenie znajdziemy na przykład w twórczości eponima Leningradu. Zob. W.I. Lenin, Państwo a rewolucja. Nauka marksizmu o państwie i zadania proletariatu, [w:] idem, Dzieła wybrane, t. 2, Warszawa 1949, s. 7. A zatem zanim nie zostanie definitywnie złamana potęga burżuazji, państwo dalej będzie grać swoją rolę, polegającą na pilnowaniu, aby antagonistyczne ,klasy [...] nie pożarły nawzajem siebie i społeczeństwa w bezpłodnej walce”, F. Engels, Pochodzenie rodziny, własności prywatnej i państwa. W związu z badaniami Lewisa H. Morgana, Warszawa 1979, s. 12. Dlatego też, póki będzie istnieć walka klas, państwo nie zniknie. Z tego właśnie względu żadna państwowość nie określiła się jako komunistyczna.

7 Znajdziemy go w Szwajcarii, gdzie co prawda w systemie organów państwowych występuje Prezydent, ale jego ustrojowa tożsamość sporo się różni od tej, którą ma określana tym mianem głowa państwa w innych krajach. W helweckim przypadku właściwie w ogóle nie ma tej przeniesionej z absolutnej francuskiej monarchii konstrukcji, a wybierany na zaledwie roczną kadencję Prezydent z lubością określany jest jako pozbawiony solidnych kompetencji primus inter pares, nieroszczący sobie żadnych pretensji do jakiegokolwiek pseudomonarchicznego blichtru. Tak właśnie przejawia się autentyczny, solidnie zakotwiczony od początku istnienia Szwajcarii w jej społeczno-politycznej rzeczywistości republikanizm, nieprzenoszony do innych państw ze względu na radykalizm czy też konsekwencję sprawiające, że nie pasuje tam, gdzie, jak na przykład w Polsce, równościowa ideologia jest chętnie werbalizowana, ale dość słabo zakorzeniona w zbiorowej (pod)świadomości. 
rodowód elitarystycznym Trybunałem Stanu, którego znamienny come back w stanie wojennym stanowił zapowiedź przejścia z ,siermiężnego socjalizmu” do „peryferyjnego demoliberalizmu”.

Zastąpił on radykalno-demokratyczną interpretację rzeczywistości, przejawiającą się w skrajnym socjalizmie, dążącym oficjalnie w marksistowsko-leninowsko-stalinowskiej odmianie do rewolucyjnego przekształcenia światowego porządku przez zaprowadzenie apaństwowego komunizmu. Przed jego zwycięstwem w globalnej skali należało według wskazań czołowych teoretyków zaprowadzić socjalizm, do czego doszło najpierw w ZSRR, a potem w Mongolii i Tuwie. Po zajęciu przez Armię Czerwoną Europy Środkowo-Wschodniej i ulokowaniu jej w radzieckiej strefie wpływów uznano wszak, że ze względu na lokalną specyfikę będzie bardziej wskazane na początku ,wiodącego w Świetlaną Przyszłość szlaku" ustanowić na tym obszarze demokrację ludową jako presocjalistyczną formę ustrojową ${ }^{8}$.

Zauważamy zatem, że, podobnie jak dzisiaj, ówczesna władza przekonywała, przynajmniej oficjalnie, siebie i innych, iż demokracja jest jedynie słusznym ustrojem, a zatem należy ją usilnie kultywować pro publico bono w lepszym wydaniu niż te, z którymi eksperymentowano nad Wisłą w okresie przedrozbiorowej demokracji szlacheckiej lub międzywojennej burżuazyjnej (burżuazyjno-obszarniczej) wersji opartego na wielkim liczebnie Zbiorowym Podmiocie Suwerenności i urzeczywistnianego już w antycznych Atenach paradygmatu władania. Opiera się on założeniu, że ,ilość przechodzi w jakość" ", a zatem trzeba usilnie dążyć do zaprowadzenia pantokracji, gdyż im mniej ludzi jest pozbawionych praw politycznych, tym lepiej. Dlatego też należy usilnie przeciwstawiać się

${ }^{8}$ Rozstrzygnięcie to znalazło swoje odbicie w Konstytucji Lipcowej, która expressis verbis postanawia, czy też potwierdza, w swoim art. nr 2, że „Polska Rzeczpospolita Ludowa jest państwem demokracji ludowej”, Konstytucje Rzeczypospolitej. 1997, 1952, 1935, 1921, 1791, red. J. Boć, Wrocław 2001, s. 12. Można stanąć na stanowisku, że gdyby to było oczywiste, to nie zaszłaby potrzeba umieszczania takiej deklaracji w ustawie zasadniczej. Miała ona na celu zademonstrowanie urbi et orbi (a przy okazji utrwalenie w świadomości, względnie „rewolucyjnej jaźni” ojców Konstytucji), że nad Wisłą jest już inaczej niż onegdaj wskutek znaczącego progresu w społeczno-politycznej sferze, jaki dokonuje się w rezultacie ,głębokich przemian, trwale zmieniających krajową rzeczywistość”, które, jak dowodzono, nie mogły mieć miejsca w „,nieludowej”, czyli burżuazyjnej demokracji.

9 Jest to progresywny dziewiętnastowieczny dogmat, umieszczony przez współtwórcę marksiszmu w zbiorze trzech podstawowych praw dialektyki. Czytamy o nim: „Prawo to możemy dla naszych celów sformułować w ten sposób, że zmiany jakościowe w przyrodzie mogą dokonywać się tylko w rezultacie ilościowego narastania lub ubywania materii albo ruchu”, F. Engels, Dialektyka przyrody, Warszawa 1969, s. 132. Przenosząc to założenie do społeczno-politycznej sfery, uznamy, że rosnące umasowienie polityczności przyniesie korzystne skutki w postaci dopuszczenia do partycypacji w procesach decyzyjnych krzywdzonego przez stulecia plebsu, który nie zasłużył sobie na taki los, a ze względu na duży potencjał ,zdrowego, chłopskiego rozumu” powinien odegrać niezwykle korzystną rolę na publicznej arenie. Przejęcie władzy przez doły społeczne stanowi wyraz Postępu, a zatem musi być dobre, natomiast tradycyjny monarchiczno-arystokratyczno-burżuazyjny legat powinien się znaleźć na ,śmietniku historii”. 
istnieniu tradycyjnych elekcyjnych cenzusów ${ }^{10}$, służących temu, aby jedynie $m e$, которым виднее, mogli podejmować dotyczące ogółu rozstrzygnięcia. Pogląd ten jest oficjalnie lansowany w Polsce, począwszy od ustąpienia w 1918 roku Rady Regencyjnej, z częściowym krótkim interwałem pod rządami Konstytucji Kwietniowej, pod dziś dzień, co oznacza, że wiara w konieczność nieograniczonej „wstecznymi zaporami”, a zatem wszechogarniającej, partycypacji w procesie politycznym, instytucjonalizowanej przez powszechne wybory, przetrwała $\mathrm{w}$ nienaruszonym stanie powojenne ustrojowe zawirowania.

Na konstytucyjnej płaszczyźnie owa ciągłość przejawiła się po zakończeniu II Wielkiej Wojny w tym, że ludowładztwo jest umieszczane konsekwentnie w tekstach kolejnych najważniejszych krajowych aktów prawnych zaraz po preambułach jako fundamentalna zasada ustrojowa, tyle że rozmaicie dookreślana. W 1952 roku pojawia się zatem demokracja ludowa, aby w 1976 przekształcić się w socjalistyczną ${ }^{11}$, która następnie ustąpi w ,post-PRL-u” miejsca jurydycznej, skoro mamy demokratyczne państwo prawne. Nietrudno wyciągnąć z tego wniosek, że podstawowa idea ustrojowa się nie zmienia, choć bywa nieco odmiennie interpretowana oraz werbalnie uzupełniana. Zmiana z 1976 roku miała pokazywać, że ludowodemokratyczna formuła jest już niepotrzebna, gdyż „Polacy ideowo dojrzeli”, z czego wyciągnięto wniosek, że można już oficjalnie umieścić ich Ojczyznę w ustrojowej optyce na socdemokratycznym szczeblu rozwoju.

10 Jak to zwykle bywa, zdarzają się „uzasadnione wyjątki od najbardziej nawet słusznych reguł”. Potwierdzeniem tej prawidłowości jest stworzenie w Kraju Rad kategorii „pozbawieńców” (po rosyjsku лишенць — od słowa лишить, czyli pozbawić), do której zaliczono niegdysiejszych wyzyskiwaczy, niezasługujących ze względu na niesłuszną przeszłość na to, aby móc współuczestniczyć w wyborczym ,święcie demokracji”. Sytuacja zmieniła się po uchwaleniu w 1936 r. stalinowskiej Konstytucji, kiedy to uznano, że ,antyrewolucyjne elementy” zostały już odpowiednio przeformatowane, w związku z czym można zrezygnować z szykanowania.

W Polsce Ludowej nie sięgnięto po takie rozwiązanie, co stanowi jedną z różnic w prawnokonstytucyjnych porządkach między wschodniosłowiańskim Wielkim Bratem a jego największym europejskim sojusznikiem, względnie satelitą.

11 Ma ona wciąż wielu zwolenników, akcentujących na przykład to, że ,zespolenie demokracji z neoliberalizmem powoduje trudną do rozwiązania sprzeczność, ponieważ gospodarka neoliberalna prowadzi do rozwarstwienia materialnego społeczeństwa $[\ldots]$ ceniona powszechnie w naszej kulturze demokracja - abstrahując od rozmaitych teorii tego ustroju — głosi wartość równości”, M. Szyszkowska, Nadmiar mitów, „Myśl Polska” 2021, nr 11-12, s. 11. W powszechnym odczuciu egalitaryzm jest mniej kompatybilny z niedemokratycznymi modelami ustrojowymi, zbudowanymi na zasadzie nierówności wobec prawa. Mimo to, jeśli będziemy rozpatrywać stosunki wewnątrz władczego czy też suwerennego podmiotu, to w monarchii panujący siłą rzeczy ,jest równy względem siebie samego", a w arystokracji zróżnicowania w obrębie „grupy trzymającej władzę” wcale nie muszą być większe niż w drugiej wersji pleonokracji (pozostajemy na gruncie trójdzielnego arystotelesowskiego schematu rodzajów władania), gdzie z jednej strony zinstytucjonalizowana elita polityczna jest wyposażona $\mathrm{w}$ immunitety, a $\mathrm{z}$ drugiej majątkowa rozpiętość między pucybutem a milionerem niejednego przyprawia o zawrót głowy. 
Według dosyć popularnego poglądu aktualnie żyjemy w „demokracji bezprzymiotnikowej”" ${ }^{12}$, które to określenie ma uświadamiać, że przeszliśmy z niewłaściwej postaci ludowładztwa do jego lepszej odmiany, pozbawionej precyzujących, względnie ograniczających dodatków. Nie należy wszakże za bardzo się przejmować tym leksykalno-semantycznym zabiegiem, bo wystarczy chwila namysłu, aby uznać, że „demokracja zawsze jest 'jakaś",13, z czego jednoznacznie wynika, że przy Okrągłym Stole co prawda porozumiano się co do konieczności zmiany, ale zdaje się, że nikt nie miał zamiaru wyjść poza ,zaklęty krąg demokracji”, z jednakowym zapałem czczonej po obu stronach Muru, którego upadek sprawił, że realny socjalizm ustąpił przed „tryumfującą burżuazją”, ale nie spowodowało to bynajmniej podważenia wspólnego dla progresywnej porewolucyjnej Europy ideologiczno-ustrojowego fundamentu. Ergo zastąpienie jednej odmiany demokracji drugą jest trudne do przeoczenia, ale nie należy przeceniać jego znaczenia.

Słuszność tego przeświadczenia łacno się ugruntuje wówczas, gdy zdamy sobie sprawę z tego, że możemy uznać, iż demokracja przymiotnikowa niezwykle często w postantycznym świecie występuje w formie demokracji parlamentarnej. Nie zaszkodzi przypomnieć w tym miejscu, że parlamentaryzm nie pojawia się w Starożytności, kiedy to przejawia się najautentyczniejsza, pozbawiona pośrednictwa, „będąca przedmiotem demofilnego kultu upolityczniona plebejskość”. To właśnie wtedy uprawia się najbardziej bezprzymiotnikową demokrację, która straciła grunt pod nogami wówczas, gdy upadły miasta-państwa, ustępując

12 Czytamy zatem na przykład taki wywód: „Demokracja — ta bezprzymiotnikowa - nieuchronnie zakłada nie tylko władzę większości, wyrażoną w wyborach, ale także to, by ten efekt wyborczy był ugruntowany pewnymi wolnościami i uprawnieniami obywatelskimi, bez których nie ma mowy o wolnych wyborach", W. Sadurski [prow. wywiad M. Bronikowski], W Polsce istnieje przyzwolenie na dyskurs faszystowski, https://wiadomosci.onet.pl/tylko-w-onecie/wojciech-sadurski-populizm-jest-reakcja-na-niedostatki-demokracji-liberalnej/n7hc6fl (dostęp: 12.03.2021). Bezprzymiotnikowość zachodniej inkarnacji demokratycznego ideału ma się kojarzyć z bezalternatywnością, gdyż przymiotnik może przecież pochodzić od faszyzmu. W każdym razie, podobnie jak w okresie realnego socjalizmu, nie dopuszcza się opcji wyjścia z apologetyzowanego wariantu ustrojowego, bo przecież „nie może i nie powinno być inaczej”.

13 „Min. Waszczykowski myli się, sądząc, że istnieje coś takiego jak 'demokracja bezprzymiotnikowa'. Demokracja zawsze jest 'jakaś', a to właśnie jej przymiotnik określa jej realny charakter, ponieważ demokracja demokracji nierówna [...]. Minister podał też przykłady nielubianej przezeń demokracji przymiotnikowej: »Byliśmy kilkanaście lat w temu w demokracji socjalistycznej, na wschód od nas próbują zbudować demokrację suwerenną, na zachód od nas próbują stworzyć demokrację liberalną, czyli przymiotnikową «", R. Jurszo, PiS chce „,normalnej demokracji”. Liberalna mu nie pasuje. Szczera do bólu wypowiedź Waszczykowskiego, https://oko.press/pis-chce -normalnej-demokracji-czyli-jakiej/ (dostęp: 21.03.2021). Aktualnie wdrażana w Naszym Kraju wariacja ludowładztwa może być rozmaicie „oprzymiotnikowana” — na przykład jako demokracja sanacyjna, co jak najbardziej umacnia w przekonaniu, że każde istniejące w kształtowanej pierwotnie przez teoretyczny namysł praktyce ustrojowej ludowładztwo nie może się obejść bez werbalno-doktrynalnego doprecyzowania, ściągającego wysoko unoszący się w sferze platońskich lub paraplatońskich bytów ideał na „grząski grunt mozolnego urzeczywistniania”. 
miejsca swoim wielomilionowym następcom, wskutek czego zaistniała konieczność reprezentowania interesów upodmiotowionych politycznie mas przez zasiadających w legislatywach przedstawicieli.

Fenomen ten bynajmniej nie ominął polskiej ziemi. Zostaje on na konstytucyjnym poziomie sformalizowany w znanym pod nazwą Nihil novi dokumencie, co oznacza, że już na początku XVI stulecia rodzimy parlamentaryzm ma się całkiem dobrze i od tamtej pory konsekwentnie towarzyszy upaństwowionym dziejom naszego narodu. Prawidłowość ta nie została zanegowana po znalezieniu się Polski w radzieckiej strefie wpływów, kiedy to co prawda po sławetnym referendum z 1946 roku bikameralizm ustąpił miejsca jednoizbowości, niemniej jednak parlamentarny paradygmat nie został zanegowany. Tak samo jak przed rzekomym „końcem komunizmu w Polsce”, który miał nastąpić według znanego medialnego oświadczenia „czwartego czerwca roku pamiętnego"14, także dzisiaj

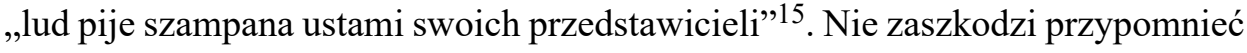
wiekopomne stwierdzenie Filozoficznego Ojca Wielkiej Rewolucji Francuskiej, który znamiennie orzekł: „lud angielski sądzi, że jest wolny, lecz myli się bardzo; jest wolny tylko podczas wyborów członków parlamentu" ${ }^{\prime 16}$. To Spiżowe Przesłanie od przedwiośnia Nowoczesności nieustannie jest obecne w rodzimym ustrojowoprawnym modelu państwowości i nie zanosi się na to, żeby miało się to zmienić, choć nikt spośród ludzi, może z wyjątkiem wyjątkowo przenikliwych

14 Tako orzekła Joanna Szczepkowska, której celebrycka wypowiedź zrobiła potężne wrażenie, gdyż w symplicystyczny sposób ustanowiła granicę między „wczorajszym absolutnym Złem a dzisiejszym bezwzględnym Dobrem”. Tego typu wyraziste dzięki swej jednoznaczności deklaracje zapadają w pamięć wskutek abstrahowania od skomplikowania prawnopolitycznej strony rzeczywistości. No bo przecież „komuny” na tej płaszczyźnie nie było, komunizm nie jest bowiem kompatybilny z jakąkolwiek państwowością, powstałą według socjalistycznej wersji dziejów wskutek pojawienia się prywatnej własności, zagrożonej przez pozbawionych ich części niegdyś rozumianego materialnie Wspólnego Dobra członków uciśnionej klasy. Socjalistyczna republika, mimo przynajmniej teoretycznego zniesienia klasowych przeciwieństw, ex definitione nie pozbywa się państwowej tożsamości, co oznacza, że w formalnoprawnym aspekcie dopiero przygotowuje nadejście wytęsknionego przez wielu komunizmu. Inaczej rzecz ujmując, komentowany skrót myślowy był i pozostaje politycznie słuszny, ale nie należy go zbyt dosłownie rozumieć.

15 Tę PRL-owską mądrość wyraził w swoistym, wyrażającym zastanawiającą osobowość „pszennego mędrka” stylu „Gdański Sfinks”, gdy po elekcyjnym tryumfie w 1990 r. skierował w stronę elektoratu wyrazistą frazę ,zdrowie wasze w gardła nasze”. Rzeczony Lech Wałęsa wyraził w ten sposób, zgodne z przesłaniem z chłopa król, ugruntowujące się przypuszczalnie w jego świadomości przekonanie co do przeskoczenia do wyższej sfery. Jej istnienie w powszechnej świadomości nie jest przypuszczalnie kwestionowane w jakimkolwiek ustrojowym porządku przez obdarzonych common sense ludzi, co jak najbardziej potwierdza przeświadczenie, że „zawsze jest tak samo”.

16 J.J. Rousseau, Umowa społeczna, Warszawa 1966, s. 113. Owa elekcyjna swoboda też nie jest bynajmniej nieograniczona, ponieważ głosuje się zazwyczaj na eksponentów elity, dysponujących umożliwiającymi przeprowadzenie potencjalnie skutecznej kampanii wyborczej finansowymi i innymi środkami. Parlamentarna elekcja polega zatem przeważnie na obstawianiu odpowiednio nagłośnionych elitariuszy, którzy w ontologiczno-politycznym wymiarze nie różnią się za bardzo od działających w oficjalnie niedemokratycznych ustrojach elitarystów. 
proroków, nie jest tak mądry, aby przewidzieć „kształt przyszłych zdarzeń”. Jeśli zatem nie dojdzie do jakichś megawstrząsów, to parlamentaryzm w dalszym ciągu będzie dzielnie trwał, pełniąc funkcję „Arki Przymierza między dawnymi i nowymi laty", dzięki czemu potwierdzi się przekonanie odnośnie do braku jakościowej, względnie ontologicznej przepaści między przedokrągłostołową a dzisiejszą wersją rodzimego paradygmatu sformalizowanego władania.

Nie oznacza to oczywiście, że nie ma różnic. Oprócz już wymienionych nie zaszkodzi wspomnieć o filozoficzno-polityczno-jurydycznej zmianie sposobu postrzegania aparatu sformalizowanego władania, która sprawiła, że w doktrynalnym ujęciu legislatywa stała się mniej ważna niż przedtem. Otóż aktualnie aplikuje się u nas monteskiuszowski dogmat podziału władzy państwowej, podczas gdy poprzednio hołdowaliśmy russowskiemu przekonaniu co do konieczności stania na twardym gruncie zasady jedności władzy państwowej jako znacznie bardziej kompatybilnej z wizją wszechogarniającej Volonté Générale. Owa Wola Powszechna nie powinna być rozdrabniana wskutek samodzielnych poczynań odseparowanych od siebie podmiotów władzy państwowej, szachujących się nawzajem za pomocą wymyślnych checks and balances. Skoro Lud Pracujący Miast i Wsi, względnie drugi suweren w postaci Narodu Polskiego, był traktowany jako pozbawiony istotnych wewnętrznych rozróżnień konglomerat, to per analogiam tak samo należało postrzegać aparat władania. Ujęcie to znajduje swe oparcie w zdroworozsądkowym przekonaniu co do tego, że musi istnieć kooperacja wewnątrz systemu władania, aby mógł on funkcjonować. Dosłownie rozumiany monteskiuszowski dogmat skutkowałby rozpadem państwowości, rozdzieranej przez odrębne polityki trzech podstawowych oraz innych władz, dlatego też należy traktować go cum grano salis ${ }^{17}$.

17 Zresztą, gdyby oprzeć się na dosłownym brzmieniu odpowiedniego przepisu, to zauważymy, że ustrojodawca nie zaordynował szatkowania władzy na najwyższym instytucjonalnym poziomie, skoro w odnośnym przepisie czytamy: „Ustrój Rzeczypospolitej opiera się na podziale [...] władzy ustawodawczej, władzy wykonawczej i władzy sądowniczej”, Konstytucje Rzeczypospolitej..., s. 15. W stricte leksykalnym wymiarze nie dokonuje się w takim ujęciu podziału całej władzy, lecz jej poszczególnych części. Zdaje się, że według językowych reguł deklarowanie rozdziału na wyższym szczeblu brzmiałoby na przykład: „Władza w Rzeczypospolitej dzieli się na ustawodawczą...”. Nie jest to bynajmniej jedyna występująca w „Miłościwie Panującej” Konstytucji wątpliwość, ale ta ma szczególne znaczenie, bo chodzi przecież o mającą niebagatelne znaczenie doktrynalną deklarację. W przekonaniu o słuszności powyższego rozumowania utwierdzimy się, gdy przeczytamy w książce renomowanego konstytucjonalisty, że „Konstytucja nawiązuje do idei podziału władz [Locke’owi oraz Monteskiuszowi chodziło raczej o podział absolutnej władzy monarszej, choć zagadnienie wtórnego podziału też występuje - A.Ł.] [...] Działalność państwa zostaje $[. .$.$] podzielona na trzy rodzajowo różne sfery działania, funkcje. Sprzyja to zachowaniu$ jedności władzy państwowej w rękach suwerena (narodu, ludu) [...]”, B. Banaszak, Konstytucja Rzeczypospolitej Polskiej. Komentarz, Warszawa 2009, s. 82. Nie zapomina się więc w doktrynie mimo ustrojowych przemian o Fundamentalnej Jedności Zbiorowego Podmiotu Suwerenności. W poprzednim ustroju była ona bardziej oczywista, co wiązało się z tym, że nie było powyżej przy- 
Jeśli chodzi o drugą z nich, czyli egzekutywę, to w PRL-u, podobnie jak teraz, dominującą rolę odgrywała w niej Rada Ministrów, kierująca, tak samo jak to ma miejsce dzisiaj, administracją państwową. Obecnie na podstawie ust. 2 art. 10 ustawy zasadniczej władza wykonawcza obejmuje też Prezydenta ${ }^{18}$, ale logika charakterystycznego zarówno dla PRL-u, jak i III RP, parlamentarno-gabinetowego systemu rządów ${ }^{19}$, nawet „zracjonalizowanego”, jaki ponoć został zainstalowany w RP, sprawia, że de facto więcej władczych narzędzi powinno znajdować się w rękach popieranego przez sejmową większość premiera. Tak jest w Zjednoczonym Królestwie, skąd z uporem godnym podziwu importuje się powstały wskutek długiej ewolucji na specyficznym wyspiarskim podłożu schemat stosunków między legislatywą a administracyjnym centrum państwowości. W Anglii szef gabinetu jest jednocześnie liderem zwycięskiego w elekcji niższej izby stronnictwa, co czyni z niego najważniejszego polityka w państwie, tymczasem w Warszawie taka sytuacja rzadko się zdarza i to zarówno w czasach II RP, jak i później. Po zamachu majowym Piłsudski nie miał ochoty bawić się ani w prezydenturę, ani w premierostwo, które to podejście spotkało się ze zrozumieniem po kolejnej Wielkiej Wojnie, kiedy to zazwyczaj przywódcy PZPR-u nie chcieli tracić cennego czasu na żmudne koordynowanie poczynań ministrów. Taki modus operandi nie zmienił się na kolejnym etapie państwowych dziejów największego spośród zachodniosłowiańskich narodów, gdyż czymś typowym podczas ostatniego trzydziestolecia okazuje się sytuacja jak najbardziej przypominająca to, co działo się w międzywojennej Rzeczypospolitej. Mianowicie rzadko kiedy

bliżonego zawikłania, z czego wynika, że nie tylko socjalizm, ale także postsocjalizm „bohatersko rozwiązuje stwarzane przez siebie problemy".

Poza wszystkim Konstytucja PRL-u była krótsza i stanowiła lepszą emanację niekoniecznie łatwej, jak się okazuje, jurydycznej sztuki. Wyrażała „parę pojęć jak cepy” (Z. Herbert, Potęga sma$k u$, https://fundacjaherberta.com/biblioteka-herberta/wiersze/potega-smaku/, [dostęp: 14.03.2021]), zsymplicyzowanych na użytek przeciętnego czytelnika pozytywnoprawnego Ius Supremum, które zostało zgrabnie ułożone przez nierozdzieranego pluralistycznymi sprzecznościami Stefana Rozmaryna.

18 „Władzę wykonawczą sprawują Sejm i Senat, władzę wykonawczą Prezydent Rzeczypospolitej Polskiej i Rada Ministrów, a władzę sądowniczą sądy i trybunały”. To rozpisanie ról nie jest do końca jednoznaczne, bo przecież ,członkowie rządu wchodzą w skład parlamentu (lub na odwrót)", K. Complak, Zasada podziału władz, [w:] R. Balicki et al., Komentarz. Konstytucja Rzeczypospolitej Polskiej, Warszawa 2014, s. 23. W Polsce Ludowej nie było inaczej, gdyż takie rozwiązanie stanowi przeniesione znad Tamizy jądro parlamentarno-gabinetowego systemu rządów, który na dobre się u nas rozgościł.

19 W 1944 r. w Polsce Lubelskiej eksperymentowano z czymś w rodzaju środkowoeuropejskiej wariacji helweckiego komitetowego systemu rządów, skoro powstał Polski Komitet Wyzwolenia Narodowego, ale szybko zrezygnowano z tego konceptu na rzecz „burżuazyjnego syntetyzowania średniowiecznego parlamentaryzmu z wczesnonowożytną monarchiczną gabinetowością". Ponieważ „wszystko już było”, bo „historia lubi się powtarzać”, to wypada wspomnieć, że mieliśmy do czynienia z odtworzeniem sekwencji z początków II RP, skoro „XX-wieczne przejawy rządów zgromadzenia zauważamy głównie we Francji, lecz także w Polsce pod rządami małej konstytucji z 1919 r.”, M. Wiszowaty, System komitetowy. Parlamentarno-komitetowy system rządów, [w:] Leksykon prawa konstytucyjnego. 100 podstawowych pojęć, red. A. Szmyt, Warszawa 2010, s. 596. 
znaczący polityk w postaci partyjnego lidera zostaje premierem, który w takim stanie rzeczy jako pozbawiony własnego kadrowego zaplecza administrator „,kierowany jest z tylnego siedzenia" 20 .

Tak nacechowane postępowanie skłania do uznania, że polska odmiana opartego na monarchiczności, jednomandatowych okręgach wyborczych i systemie dwupartyjnym brytyjskiego wzorca podlega ,sztukowaniu”, do czego zachęca niezmiennie kontynuowana po Okrągłym Stole formuła koalicyjnego rządu. W tamtym systemie zazwyczaj hegemonia PZPR-u nie ulegała wątpliwości, natomiast współcześnie już tak nie jest, co nie przyczynia się do stabilizacji na rządowym poziomie, trudnej do osiągnięcia w sytuacji sejmowej wielopartyjności. Większościowe wybory do niższej izby rodzimej legislatywy zapewne zmieniłyby ten stan rzeczy, ale akurat w tym wypadku zdecydowano sięna odejście od PRL-owskiego rozwiązania na rzecz „ukochanej przez prawdziwych demokratów proporcjonalności”.

Inną instytucjonalną odmiennością jest nie bez powodu nieobecny w dotychczasowych rozważaniach Senat, ponownie umieszczony w krajowym prawnopolitycznym pejzażu wskutek taktycznego posunięcia strony koalicyjno-rządowej przy Okrągłym Stole i następnie „opromieniony aurą pierwszych powojennych wolnych wyborów", co nie przeszkodziło bynajmniej temu, że odgrywa on marginalną rolę jako „słabsza kopia Sejmu”21. Wynika z tego, że polski parlamentaryzm jest ilościowo bardziej zróżnicowany niż przed 1989 roku, ale jakościowa różnica mogłaby być wyrazistsza, gdyby Izba Refleksji w swoim obecnym kształcie nie potwierdzała ockhamowskiej przestrogi odnośnie do zbędności mnożenia bytów ponad konieczność.

Cokolwiek by o niej jednak mówić, to jest ona, obok Prezydenta, symbolem instytucjonalnej przemiany nieobecnego w najnowszej Konstytucji PRL-u w III RP. Tego samego nie można powiedzieć o zainstalowanym w prawnopolitycznym

20 Dosadnie znaczenie szefa ogólnopaństwowej administracji ujął w swoim potoczystym stylu Lech Wałęsa, gdy stwierdził à propos Jana Krzysztofa Bieleckiego, że „wziął premiera z III ligi”, aby zastąpić Tadeusza Mazowieckiego, który też został wyciągnięty przez „Gdańskiego Sfinksa” z trzeciego szeregu dzięki politycznej woli Silnego Człowieka, wyznaczającego w sposób budzący skojarzenie z niegdysiejszymi monarchicznymi praktykami wykonawcę Wyższej Woli. Z tego schematu jak do tej pory wyłamali się tylko Leszek Miller i Donald Tusk oraz na krótko Jarosław Kaczyński, który wszakże, jak widać, nie ma specjalnej ochoty ponawiać tej próby. Kusi, aby wytłumaczyć taką niechęć brakiem wiary w możliwość uprawiania prawdziwej Wielkiej Polityki na stanowisku pierwszego ministra, gdzie trzeba się zmagać ze skrzeczącą rzeczywistością, co nie pomaga w konstruowaniu dalekosiężnych projektów, albowiem takie zajęcie wymaga czasu i dystansu od codziennej „bieżączki”.

21 Trzeba w dużej mierze przyznać rację uczonemu autorowi wydanej na potrzeby referendalnej kampanii w 1946 r. broszury, noszącej znamienny tytuł. Zob. K. Grzybowski, Senat albo antydemokratyczny, albo niepotrzebny, Łódź 1946, passim. W dzisiejszym kształcie niegdysiejsza wyższa izba jest pozbawiona odrębnej tożsamości. Przydałoby się więc albo ją zlikwidować, albo radykalnie przekształcić po to, by wyrażała inną, choćby postulowaną w niektórych środowiskach korporacyjno-arystokratyczną filozofię, co pozwoliłoby zróżnicować przesadnie demokratoidalny rodzimy ustrojowy krajobraz. 
systemie Polski Ludowej kilka miesięcy przed Sierpniem 1980 roku Naczelnym Sądzie Administracyjnym oraz Trybunale Konstytucyjnym, Trybunale Stanu, jak również Rzeczniku Praw Obywatelskich, które to organy pojawiły się w konstytucyjnym schemacie ustrojowym ,podczas ciemnej nocy stanu wojennego lub w półmroku, jaki po nim nastał". Mimo to trwają w najlepsze, taka jest bowiem Mądrość Etapu, choć znalazłyby się nienacechowane emocjonalne, wyprane z męczącej retoryki „nasilającej się walki z Komuną” argumenty na rzecz ich niekonieczności.

Na koniec wypada zaakcentować, że Polska Ludowa w jej politycznoprawnym wymiarze wciąż jest w niezłej mierze obecna w Rzeczypospolitej XXI wieku. Trudno temu jakoś specjalnie się dziwić, jeśli przy Okrągłym Stole zasiedli „pięknie się różniący” prominentni przedstawiciele jednoczącej się partyjno-solidarnościowej elity po to, by bez specjalnych wstrząsów skonstruować post-PRL. Ex definitione rzeczona postać rodzimej państwowości nie jest tożsama $\mathrm{z}$ jej poprzedniczką, czego sztandarowym przejawem są wolne, a raczej konfrontacyjne wybory, nieobecne przed ustrojową transformacją w hołdującym koncesjonowanemu pluralizmowi realnym socjalizmie. Różnica owa ma fundamentalne znaczenie dla demofilów w ich sekciarskich sporach, natomiast w szerszym oglądzie, nawet niekoniecznie in specie aeternitatis, nie musimy się nadmiernie ekscytować „przypływami i odpływami demokracji”"22, trwającymi już w Rodzinnym Kraju od dobrych kilku wieków. Gdy przyjmiemy taką gnoseologiczną perspektywę, to casus $\mathrm{w}$ poststalinowskim okresie raczej autorytarnego niż totalitarnego ${ }^{23} \mathrm{PRL}-\mathrm{u}$ siłą rzeczy podlega historiozoficznej relatywizacji, która zapewne się nasili, gdy wymrą znający Polskę Ludową z własnych doświadczeń ludzie, a potomni będą ją zestawiać z przyszłym ustrojem, który bynajmniej nie musi być liberalniejszy, jeśli założymy, że ewidentny kryzys demoliberalno-konstytucyjnego sposobu organizacji ogólnopaństwowego życia będzie się pogłębiał, co oczywiście nie jest pewne, ale jak najbardziej możliwe.

22 Zob. A. Trzaska-Chrząszczewski, Przyplywy i odptywy demokracji, Warszawa 1939, passim.

23 Czasem używa się pojęcia „,demokratura”, ale występuje także demototalitaryzm. To drugie określenie można uzasadnić przesłaniem klasycznego już w gruncie rzeczy dzieła - J.L. Talmon, U źródel demokracji totalitarnej, Kraków 2015, passim. Autor ów przekonuje, że ludowładztwo występuje bądź w liberalnej, bądź w totalitarnej formie. W obu przypadkach mamy do czynienia z ideowo wspólnym rodowodem, który w żadnej z dwóch postaci nie zostaje zanegowany, dochodzi natomiast do wzajemnego oskarżania się o przeinaczenie pierwotnego przesłania. 


\section{Bibliografia}

Banaszak B., Konstytucja Rzeczypospolitej Polskiej. Komentarz, Warszawa 2009.

Complak K., Zasada podziału władz, [w:] R. Balicki, M. Bartoszewicz, K. Complak, M. Haczkowska (red.), A. Ławniczak, M. Masternak-Kubiak, Komentarz. Konstytucja Rzeczypospolitej Polskiej, Warszawa 2014.

Engels F., Dialektyka przyrody, Warszawa 1969.

Engels F., Pochodzenie rodziny, własności prywatnej i państwa. W zwiąku z badaniami Lewisa H. Morgana, Warszawa 1979.

Grzybowski K., Senat albo antydemokratyczny, albo niepotrzebny, Łódź 1946.

Herbert Z., Potęa smaku, https://fundacjaherberta.com/biblioteka-herberta/wiersze/potega-smaku.

Jurszo R., PiS chce „normalnej demokracji”. Liberalna mu nie pasuje. Szczera do bólu wypowiedź Waszczykowskiego, https://oko.press/pis-chce-normalnej-demokracji-czyli-jakiej.

Konstytucja Polskiej Rzeczypospolitej Ludowej uchwalona przez Sejm Ustawodawczy 22 lipca 1952 r., http://isap.sejm.gov.pl/isap.nsf/download.xsp/WDU19520330232/O/D19520232.pdf.

Konstytucje Rzeczypospolitej. 1997, 1952, 1935, 1921, 1791, red. J. Boć, Wrocław 2001.

Kozerska E., Scheffler T., Retoryka ciagłości: o dziedzictwie prawnym II Rzeczypospolitej i rządach komunistycznych, „Studia nad Autorytaryzmem i Totalitaryzmem”39, 2017, nr 2.

Lenin W.I., Państwo a rewolucja. Nauka marksizmu o państwie i zadania proletariatu, [w:] Lenin W.I., Dzieła wybrane, t. 2, Warszawa 1949.

Ławniczak A., Masternak-Kubiak M., Republikańska forma państwa w ujęciu Konstytucji RP, „Państwo i Prawo" 1999, nr 8.

Persak K., ,, Troskliwy opiekun i światty doradca Polski Ludowej - poprawki Józefa Stalina do Konstytucji PRL z 22 lipca 1952 r., [w:] PRL. Trwanie i zmiana, red. D. Stola, M. Zaremba, Warszawa 2003.

Rousseau J.J., Umowa społeczna, Warszawa 1966.

Sadurski W. [prow. wywiad Bronikowski M.], W Polsce istnieje przyzwolenie na dyskurs faszystowski, https://wiadomosci.onet.pl/tylko-w-onecie/wojciech-sadurski-populizm-jest-reakcja-na-nie dostatki-demokracji-liberalnej/n7hc6f1.

Szyszkowska M., Nadmiar mitów, „Myśl Polska” 2021, nr 11-12.

Talmon J.L., Uźródet demokracji totalitarnej, Kraków 2015.

Trzaska-Chrząszczewski A., Przyptywy i odplywy demokracji, Warszawa 1939.

Wiszowaty M., System komitetowy. Parlamentarno-komitetowy system rząów, [w:] Leksykon prawa konstytucyjnego. 100 podstawowych pojęć, red. A. Szmyt, Warszawa 2010. 